UDK 784.3 Lisinski + Livadić

Koraljka Kos Zagreb

\section{VOKALNA LIRIKA VATROSLAVA LISINSKOG I FERDE LIVADIĆA U EVROPSKOM KONTEKSTU}

"Da si muzikalnih idea pridobavim, preigrao sam marlivo skorom sva dela Beethovena, Bacha, Mozarta $i$ Hajdena, no do kakve doveršenosti dojti meni moguće nije bilo, poradi teranja vekšnega gospodarstva, koje na jedinu moju osobu napartjeno bilo..."

(Iz pisma Ferde Wiesnera-Livadića Petru Preradoviću, Samobor, 5. prosinca 1863) ${ }^{1}$

Popijevkama Vatroslava Lisinskog posvećeno je dosad nekoliko istraživanja, dok su Livadićeve privukle manju pozornost. ${ }^{2}$ Ovaj je rad usmjeren na sagledavanje njihova mjesta u kontekstu evropskoga Lieda prve polovine 19. stoljeća, upozoravajući na srodnosti i veze, ali i specifičnosti njihove vokalne lirike. Za analize i usporedbe upotrijebljene su objavljene popijevke dvojice skladatelja ${ }^{3}$ kao i dostupna arhivska gradja u Nacionalnoj i sveučilišnoj biblioteci, Hrvatskom glazbenom zavodu i u Arhivu Hrvatske u Zagrebu; od stranih su autora pregledani radovi u njima suvremenim zbirkama ili u novim izdanjima. Intenzivniji kontakt s većim brojem djela potvrdio je prve spontane dojmove i omogućio diferenciraniju analizu i ocjenu popjevaka Lisinskoga i Livadića, koje količinom i vrijednošću predstavljaju dio baštine evropskog Lieda.

$U$ drugoj polovini 18 . stoljeća potreba za popijevkama potiče stvaranje brojnih zbirki s radovima jednostavne, dopadljive melodike i diskretne akordske pratnje. ${ }^{4}$ Vla-

1 Citirano prema tekstu koji je Franjo Kuhač objavio u okviru Livadićeve biografije u časopisu Vienac, 1891, br. 19.

2 Izdvajamo sljedeće radove: Lovro Županović, Vatroslav Lisinski (1819-1854). Život, djeIo, značenje, Jugoslavenska akademija znanosti i umjetnosti, Zagreb 1969, str. 132 -188; Koraljka Kos, Nekatere posebnosti vokalne melodike Vatroslava Lisinskega, Muzikološki zbornik, VII, Ljubljana 1971, str. 39-48; Koraljka Kos, Die Grazer Jahre des Ferdo Wiesner-Livadić (1816-1822), u: Studien zur Musikgeschichte des Ostalpen- und Donauraums I, Grazer Musikwissenschaftliche Arbeiten, 5, hrsg. von Rudolf Flotzinger, Graz 1983, str. 73-91.

3 Izdanja: Neuvelo cvieće, izabrane popievke slavnoga hrvatskoga glasbotvorca Vatroslava Lisinskoga (ured. Fr. Ks. Kuhač), Zagreb, F. Župan (1905); Vatroslav Lisinski, Solo popijevke (Izabrana djela, I), priredio Lovro Županović, Udruženje kompozitora Hrvatske, Zagreb 1969; Tri solo-popijevke F. Livadića, obj. L. Županović, Iz baroka u romantiku, Croatia Concert, Zagreb 1978. (Spomenici hrvatske glazbene prošlosti, IX)

4 O zanimljivim predgovorima takvim zbirkama piše Arnold Feil u članku Zur Genesis der Gattung Lied wie sie Franz Schubert definiert hat, Muzikološki zbornik XI, Ljubljana 1975, str. $40-53$. 
dajuća stvaralačka estetika predšubertovske solo pjesme ogleda se i u shvaćanjima Johanna Wolfganga Goethea koji odbacuje prokomponiranu popijevku, očekujući od Lieda da bude tek okvir za poeziju, "zračni balon" koji će stihove ponijeti u visine. ${ }^{5} \mathrm{Ve}$ za tekst - glazba ostvaruje se u jednostavnom i kontinuiranom toku, bez složenijih odnosa; glazba teži da slušaoca prenese u ugodjaj koji sugeriraju stihovi. Tek će Franz Schubert ostvariti Lied kao umjetničku vrstu vlastita profila, primjenjujući tekovine klasične instrumentalne polifonije u okviru jedinstvenog vokalno-klavirskog sloga. Od njegova se Lieda razlikuju solo pjesme većine romantičara, koji samo nastavljaju tradiciju Lieda 18. stoljeća obogaćujući ga novim nijansama, ali ne mijenjajući u suštini odnos poezija - glazba; ona ostaje tek okvir za stihove, ostvarujući opći ugodjaj kojim oni zrače.

Na putu sazrijevanja solo pjesme kao umjetničke forme zanimljiva je ličnost njemačkog skladatelja, štutgartskog dvorskog kapelnika Johanna Rudolfa Zumsteega (1760-1802). ${ }^{6}$ Ovaj nadareni protoromantičar svoju je vokalnu glazbu često zasnivao u epskoj formi balade. Uglazbljujući opsežne narativne tekstove Zumsteeg očituje smisao za karakterizaciju pojedinačnih etapa u priči, žrtvujući prikazu niza pojedinosti mogućnost sintetskog obuhvaćanja cjeline. lako instrumentalni part njegovih balada najčešće očituje tek oprezno ispitivanje mogućnosti klavira (što je naročito zamjetljivo u samostalnim instrumentalnim interludijima), nema sumnje da je majstorova težnja slikovitosti nalazila odgovarajuće ostvarenje u izboru tonaliteta, harmonijskim sredstvima i ritmici. Od Zumsteega je učio mladi Schubert, pa su njegove rane vokalne scene i balade (spomenimo Hagars Klage i Leichenfantasie iz 1811. te baladu Der Taucher na tekst Friedricha Schillera 1814/15) zasnovane kao opsežni prokomponirani napjevi. U osloncu na Zumsteegov tip balade Schubert u tim i sličnim djelima traži u prvom redu slušateljevo sudioništvo u pojedinostima. ${ }^{7}$

Zumsteegove su balade nakon 1800. bile vrlo omiljene i raširene posredstvom tiskanih zbirki, pa je vjerojatno da su ih mogli upoznati i Lisinski i Livadić. $U$ opusu Lisinskoga nalazimo čitavu skupinu radova koji su osnovnom koncepcijom srodni Zumsteegovim baladama; radi li se o neposrednom osloncu na radove njemačkog skladatelja ili tek o analognim stvaralačkim htijenjima niklim u okvirima i uslovima budjenja ranoromantičkih stilskih težnji u Hrvatskoj - teško je pretpostaviti, a možda i nije bitno. Važnije je uočiti pripadnost evropskim duhovnim strujanjima i konkretizaciju glazbene ideje $u$ analognim skladateljsko-tehničkim postupcima.

S Zumsteegovim baladama vrijedno je usporediti opsežne radove baladičke koncepcije Vatroslava Lisinskoga: Prosjak, Der Zufluchtsort, Die Botschaft (sve nastale iste, 1846. godine, kao da je Lisinski u odredjenoj stvaralačkoj fazi htio dokraja iskušati ovaj tip popijevke) i Car Dušan (1851).

5 Usp. pismo Johanna Wolfganga von Goethea skladatelju Zelteru, 11. V. 1820; prema: F. Blume, Goethe und die Musik, Bärenreiter Verlag, Kassel 1948, str. 43; o Goetheovom negativnom odnosu prema prokomponiranoj formi v. Tag und Jahreshefte, Februar 1801.

6 Jürgen Kindermann, Johann Rudolf Zumsteeg, Die Musik in Geschichte und Gegenwart, 14, Bärenreiter Verlag, Kassel 1968, šp. 1427-1434. Za usporedbu jedne njegove balade s onima Lisinskoga predlažemo zbirku Das deutsche Sololied und die Ballade, mit einer geschichtlichen Einführung von Hans Joachim Moser, u seriji Das Musikwerk, Heft 14/15, Arno Volk Verlag, Köln 1957, gdje je objavljena balada Ritter Toggenburg, tiskana 1. puta u veljači 1800 , kod Breitkopfa i Härtela u Leipzigu.

7 O tome vidi opširnije u knjizi Walthera Dürra, Das deutsche Sololied im 19. Jahrhundert. Untersuchungen zu Sprache und Musik, Heinrichshofen's Verlag, Wilhelmshaven 1984, str. 193 i slij. 
U svim se slučajevima radi o uglazbljenju opsežnih, djelomično dijaloški zasnova. nih narativnih tekstova $s$ naglašenim elementima fantastike. ${ }^{8}$ Analiza pokazuje niz analognih postupaka u izgradnji forme u cjelini: to je, prije svega nizanje kontrastnih odlomaka u skladu sa sadržajem teksta; suprotnosti su ostvarene raznim tempima, tonalitetima, tonskim rodovima i harmonijskim sredstvima (tonalitetna zatvorenost ili modulativno otvoreni dijelovi; dijatonika ili kromatika i sl.), ilustrativnim postupcima (tonsko slikanje u klavirskom partu, skale, tremola, glissanda), raznovrsnim načinima oblikovanja vokalne dionice (naglašena pijevnost u periodičkoj zatvorenosti, poput zaokružene pjesme umetnute u veću, baladičku cjelinu; dramatska deklamacija, recitativ), promjenama metra i ritmičke okosnice, dinamike i klavirskog sloga. ${ }^{9}$

Medjutim, mada je makroforma u Lisinskoga naizgled vrlo slična Zumsteegovoj nastaloj aditivnim nizanjem odlomaka - niz pojedinosti svjedoči o naporu Lisinskoga da ove svoje opsežne skladbe (prokomponirane ili nalik rondu) glazbenim sredstvima poveže u cjelinu. Očito je, da je naizgled disparatnu formu oblikovala snažna stvaralačka volja, koja - usprkos nespretnostima - ne ispušta iz vida cjelinu djela.

Važan čimbenik u tom povezivanju dijelova u organsku cjelinu je ponavljanje pojedinih odlomaka; uvjetovano je sadržajem teksta, javlja se dakle na mjestima gdje tekst dozvoljava ili čak traži repriziranje osnovne gradje. Tako u Prosjaku Lisinski donosi osnovnu "temu" popijevke ne samo na kraju (drama je završena, prosjak nalazi smirenje), već i u sredini (uz lirski tekst „tad se vratim u me mjesto“), sada medjutim na drugom tonalnom planu, $u$ es molu (osnovni tonalitet je $d$ mol). Ovaj skladateljski vrlo produbljen potez maštovito je rješenje i faktor dinamičnosti u okviru oveće forme ove popijevke. Ponavljanje osnovne "teme" faktor je koji osigurava zatvaranje opsežnog tekstovno-glazbenog kruga u popijevci Der Zufluchtsort: na samome kraju, nakon niza kontrastnih, sad lirskih, sad dramatskih dijelova, vraćanje početnog materijala sretno zaokružuje dramu.

Osim ponavljanja pojedinih vokalnih dijelova (s pripadajućom, najčešće variranom pratnjom) Lisinski upotrebljava i druga sredstva kohezione funkcije: to su na primjer uvodni klavirski motivi koji anticipiraju pijev, dakle su dio veće glazbene cjeline; no više od ostaloga to su samostalni provodni motivi u klavirskom partu. Oni su najčešće izrazito profilirani, kao npr. zaostajalični dvotakt u Zufluchtsortu ili punktirani skokoviti motiv u Prosjaku koji svojom napetošću obilježava veći dio klavirske dionice ove popijevke. No ponekad su ti motivi prividno posve beznačajni, kao što je to uvodni motiv u popijevci Die Botschaft, koji se medjutim, tokom popijevke svojim povremenim javljanjem u klavirskoj dionici iskazuje kao jedini kohezioni čimbenik ovog opsežnog napjeva. Zanimljivo je uočiti, da Lisinski te motivičke konstante - svojevrsne kopče izmedju pojedinih disparatnih glazbenih odlomaka - najčešće elizijom uključuje u glazbeni tok, tako da se završetak vokalne fraze poklapa s početkom motiva u klavirskom partu.

Spomenuta skupina vokalnih radova Vatroslava Lisinskoga očituje i niz analognih postupaka u oblikovanju pojedinosti: tako Lisinski često ostvaruje izražajnu napetost i/ili proširenje forme ponavljanjem završnoga stiha ili dijelova stiha na kraju pojedine kitica teksta (npr. u solo pjesmi Die Botschaft tim postupkom pretvara četverotakte iz

8 L. Županović (op. cit., str. 185) upozorava na sličnost literarnih predložaka popijevke Der Zufluchtsort i Schubertovih balada Erlkönig i Der Tod und das Mädchen. Podudarnost nalazi u dramaturškom oblikovanju i individualizaciji glavnih likova. Sadržajno je slična i Livadićeva balada Okićke vrane, Arhiv Hrvatske, Ostavština F. Ks. Kuhača.

9 Usp. plan popijevke Der Zufluchtsort u prilogu; popijevka je dostupna u izdanju L. Županovića, v. bilj. 3. 
prve strofe tokom kasnijeg razvoja u šesterotakte koristeći istu gradnju). Time Lisinski ostvaruje na kraju pojedine strofe neku vrst završne poante. Osim toga skladatelj na afektivnim i dramatskim vrhuncima smisleno kida vokalnu frazu, razbijajući je pauzama i ostvarujući uvjerljivu dramatsku deklamaciju (Der Zufluchtsort, II. i III. strofa). Time lomi strogi pjesnički metar i klasičnu periodu.

Načelno se može reći da u izgradnji makroforme Lisinski sučeljava dramatske i lirske odlomke: dramatski su zasnovani kao otvoreni, naglašeno deklamacijski dijelovi, dok se lirski konstituiraju kao zatvorene pijevne cjeline.

Ne usporedjujući stvaralačke domete valja istaknuti, da je Lisinskoga pri stvaranju njegovih balada vodila stvaralačka volja srodna Schubertovoj, kada je u baladi Erlkönig (1821) raznovrsnu glazbenu strukturu objedinio jedinstvenom klavirskom pratnjom.

Car Dušan Vatroslava Lisinskoga, iako sadržajem i opsegom očituje stanovitu srodnost sa skupinom balada iz 1846, kao da u medij male vokalne forme prenosi neka iskustva skladateljeva bavljenja operom. To je dramska scena s opsežnim instrumentalnim uvodom koji ima funkciju ouverture, primjenom secco recitativa i dramatske deklamacije. Lisinski napušta četverotaktnost klasičnog nasljedja i oblikuje vokalni i instrumentalni part u složenoj interakciji, prenoseći povremeno kantilenu u instrument. U makroformi uočljiva je artikulacija koja smiono razbija shemu Preradovićeva teksta, konstituirajući ga na drugačiji, logičniji način.

Daljnji razvoj Lisinskoga na području popijevke dozvoljava još jednu razinu usporedbe s Franzom Schubertom. Nakon ranih opsežnih balada Schubert se nakon 1815. intenzivno bavi strofnom popijevkom i produbljuje ovu formu. Ova promjena interesnog težišta (prividno u suprotnosti s "razbarušenim“ mladenačkim radovima) priprema je za zrelu majstorsku fazu i sintezu zrelih godina kada skladatelj razvija razne tipove nadstrofnog Lieda. ${ }^{10}$ Pritom sve više teži sintezi vokalnog i instrumentalnog parta obuhvaćajući ih jedinstvenim slogom. Slično i u vokalnom opusu Lisinskoga nalazimo nakon 1846. razna rješenja nadstrofnog oblikovanja, u okviru kojeg se individualni, neshematizirani klavirski part stapa s vokalnim u koncentriranom lirskom iskazu. Izgleda kao da je Lisinski, vodjen snagom vlastite stvaralačke intuicije, prešao put analogan Schubertovom.

Nacionalna crta, koja je u vokalnoj lirici Lisinskoga zamjetljiva rjedje nego u nekim drugim područjima njegova stvaralaštva, očituje se povremeno kao tipično romantički couleur locale. Za razliku od prizvuka egzotike i pitoresknosti kakav povremena primjena folklorizama u funkciji ostvarenja lokalnog kolorita poprima u mnogih evropskih skladatelja 19. stoljeća, u nas on dobiva drugačije konotacije, mada se na takve postupke i u slučaju Lisinskoga može primijeniti Dahlhausova opaska o mnogoznačnosti, dakle relativnosti. Kao što naglašava Zofia Lissa, značenje takvih elemenata (kao što su na primjer „prazne kvinte" u basu, modalnost melodijskih pokreta, neki ritamski obrasci i slično) bitno ovisi o točki recepcije, tj. o poziciji slušaoca i smislu koji on projicira u djelo, a na temelju niza izvanglazbenih odrednica. ${ }^{11}$ Kao primjer za spomenutu mnogoznačnost neka posluži stilizirani narodni plesni ritam u popijevkama Stanislava

10 Walter Wiora u knjizi Das deutsche Lied. Zur Geschichte und Aesthetik einer musikalischen Gattung, Möseler Verlag, Wolfenbüttel und Zürich 1971, upotrebljava termin „nadstrofno oblikovanje” u odnosu na raznovrsne preobrazbe strofnog modela u dijelu vokalne lirike Franza Schuberta.

11 Carl Dahlhaus, poglavlje "Exotismus, Folklorismus, Archaismus" u knjigi Die Musik des 19. Jahrhunderts, Neues Handbuch der Musikwissenschaft, hrsg. von Carl Dahlhaus, sv. 6, Athenaion, Wiesbaden 1980, str. 252-261; Zofia Lissa, O nacionalnom stilu u glazbi, u zbirci eseja Estetika glazbe (ogledi) prijevod s njemačkog, Naprijed-Delo, Zagreb i Ljubljana 1977, str. $211-238$. 
Moniuszkoga (Kozak), Frederica Chopina (Narzeczony) i Lisinskoga (Tamburaška). U sva se tri slučaja radi o istom ritmu (s malim odstupanjem kod Moniuszkoga, gdje je prva nota punktirana), koji kod dvojice poljskih skladatelja asocira poljski, a kod Lisinskoga hrvatski (slavonski) narodni ambijent. (Notni primjer br. 1)
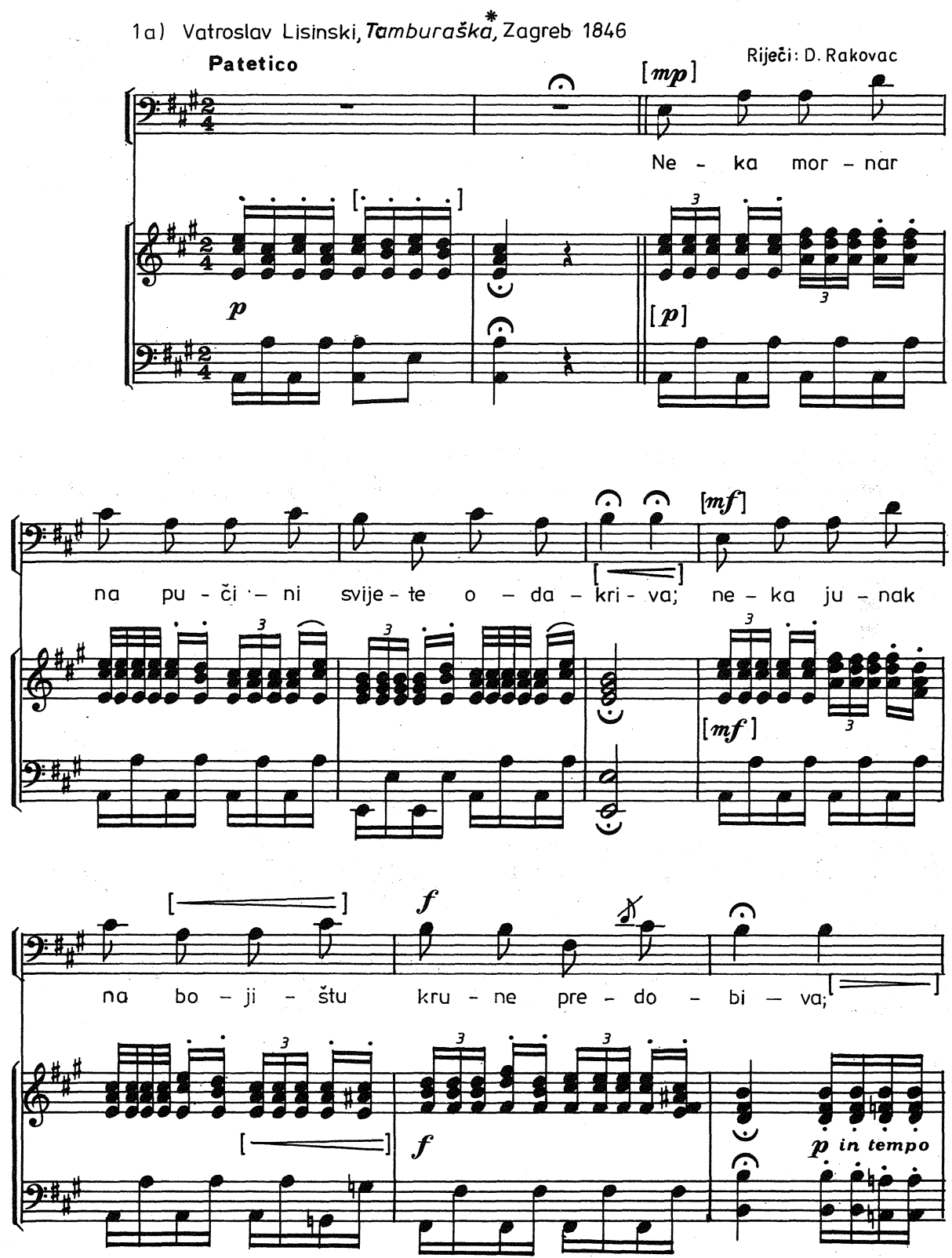

* (izd. L. Županovića, v. bilj. 3 ) 
1 b) St.Monuuszko, Kozak iz zbirke Dumki i piosnki sielskie
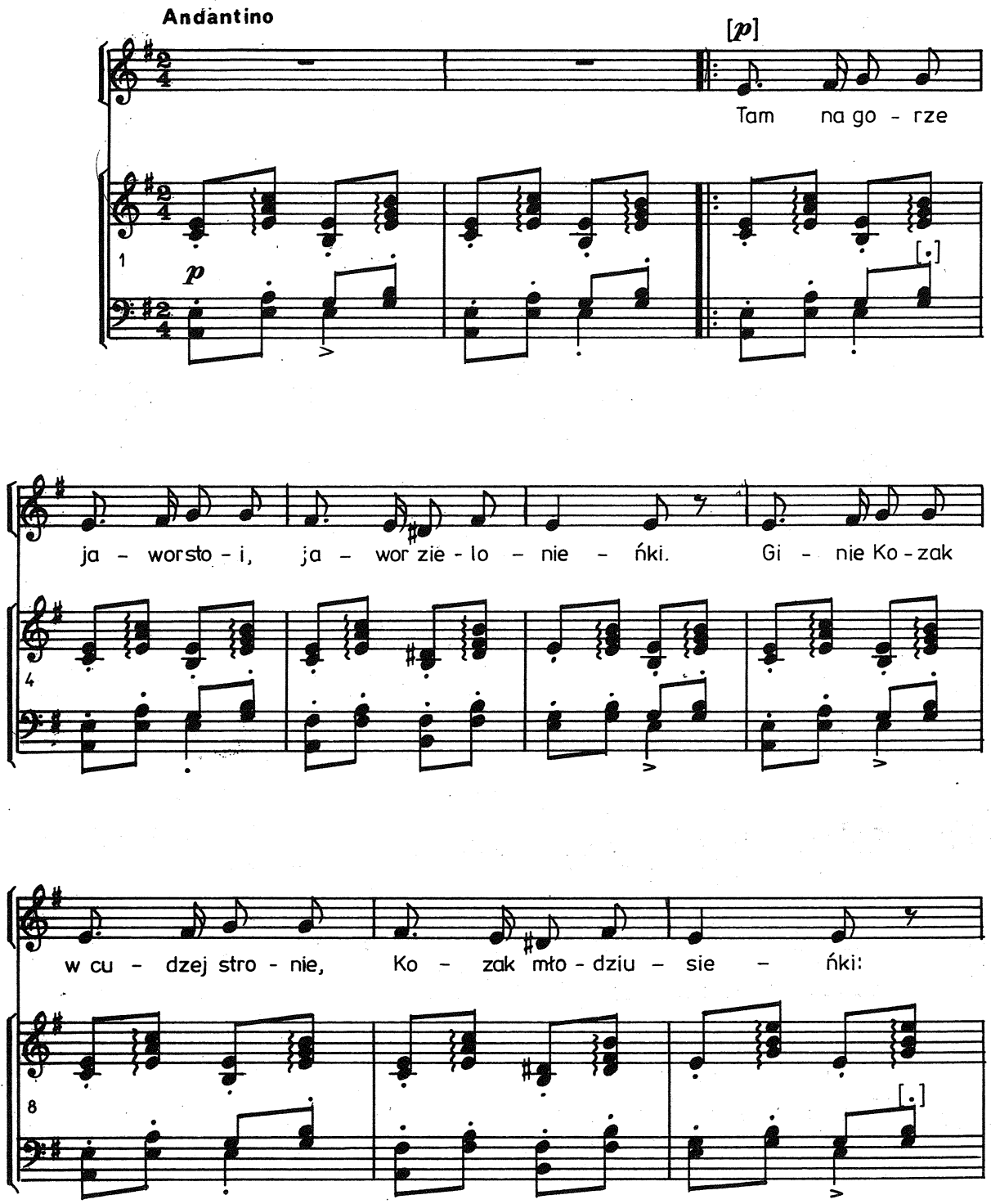

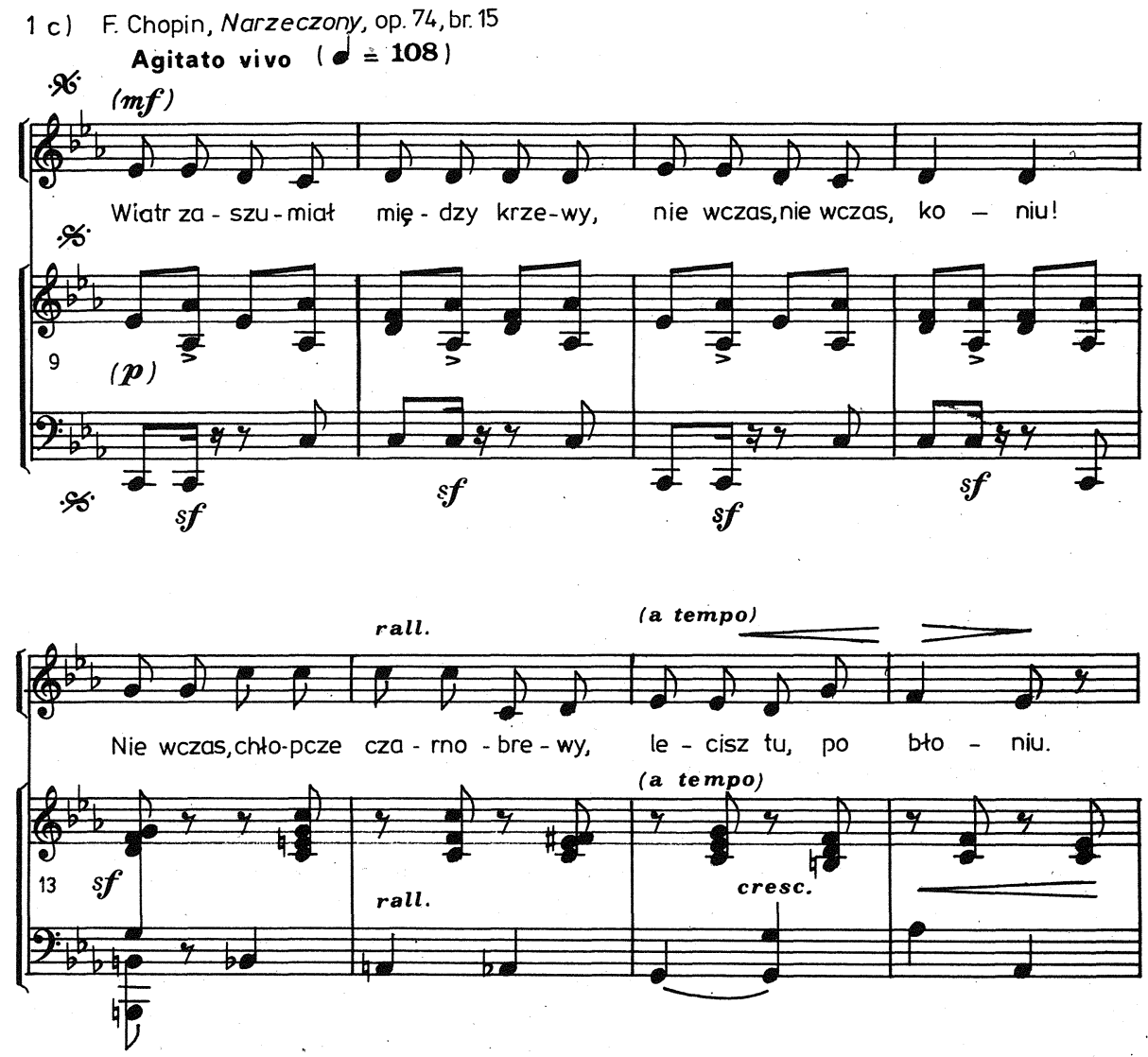

Za životni i stvaralački put Ferde Livadića presudne su bile godine njegova školovanja u Grazu (1816 - 1822). U to je vrijeme u štajerskoj prijestolnici uz ranoromantički operni repertoar snažno prisutna klasična tradicija. Livadić tada, a i kasnije uči prvenstveno na djelima klasičnih majstora, o čemu rječito govori uvodni citat u ovu studiju. Njegove riječi iz pisma Preradoviću karakteristične su i za okolnosti u kojima se na našim geografskim koordinatama vjekovima nastojalo izmiriti suprotnosti izmedju stvaralačkih težnji i realiteta. A taj realitet nije bilo samo "gospodarstvo“ kojim se Livadić - naslijedivši dobro kraj Samobora - morao baviti, već i ideologija ilirskog pokreta, koja je nesumnjivo utjecala na njegov glazbeni izraz. Jer nakon nadahnute skupine popjevaka na njemačke tekstove (nastale vjerojatno za boravka u Grazu) on - po naputku Ljudevita Gaja - traži distancu od njemačke tradicije, težeći jednostavnosti izraza.

Njegova vokalna lirika (Kuhač registrira ca 180 pjesama i zborova na hrvatske, njemačke i slovenske tekstove, a od toga je velik dio izgubljen), ${ }^{12}$ odaje u prvom redu nadarenog melodičara koji u solo pjesmi ostvaruje kontinuirani, jedinstveni tok melodi- 
je i klavirske pratnje. Svoje solo pjesme Livadić često obilježava nazivom „air" ili „romanca“. Ovim drugim nazivom (koji susrećemo i kod Mihajla Ivanoviča Glinke) Livadić upućuje na konkretni izražajni karakter i formu: romanca je - prema Kochu (1802) „pjesma koja sadrži neku tragičnu ili zaljubljenu zgodu u ilirskim stihovima i odjevena je u krajnje naivan i jednostavan stil. Melodija za taku pjesmu mora se sastojati iz neizvještačenog ali naivnog i ganutljivog pijeva". ${ }^{13}$ Radi se dakle o narativnom pjesništvu oblikovanom u lirskim stihovima, strofno i vezanom rimom, s jednostavnom glazbenom dopunom, često i u pučkom prizvuku. Upravo takve su Livadićeve romance (istaknimo kao uspio primjer popularnu Kamenu dievu), kojih jednostavnost nikada ne prelazi u trivijalnost.

Drugačije stilske utjecaje prepoznajemo u skupini popjevaka na njemačke tekstove nastalih vjerojatno za vrijeme školovanja u Grazu. ${ }^{14}$ Ovdje Livadić očituje izrazitu sklonost za trodijelnu metriku $(3 / 4,6 / 8,12 / 8)$; izgleda da mu je jednakomjerni puls osminki u trodijelnom metru pružao odgovarajuću zvukovnu pozadinu za razvoj širokih melodijskih lukova kojima se odlikuju ove popijevke. Njihove su melodije očito nastale u sferi talijanskog bel canta i njegovih vrhunskih ostvarenja u dugim melodijama (Verdi ih naziva "melodie lunghe") Bellinija i Donizettija. Livadić je uostalom ovaj izražajni model uspješno primijenio u svom klavirskom Notturnu (1822). ${ }^{15}$ (Notni primjer br. 2)

Rijetki su u Livadića pokušaji harmonijske karakterizacije teksta ili ilustrativnih detalja u klavirskoj dionici (npr. oponašanje svirke šalmaja u popijevci Die Nonne). Povremeno se javljaju recitativni umeci, tako u popijevci $O$ weine nicht! koja je stilom bliža koncertnoj ariji nego solo pjesmi. Skladatelj se u načelu zadovoljava preglednom formom, dopadljivom pijevnom melodikom i skromnom klavirskom pratnjom koju oživljava raznovrstnim oblicima akordske figuracije. Taj klasicistički okvir ostvaruje tako samo opću lirsku atmosferu u koju su stihovi uronjeni, posve na način predšubertovske popijevke i Goetheovih ideala. U skladu s takvom estetikom Livadić pažljivo bilježi nijanse za interpretaciju koje vode pjevača prema diferenciranome tumačenju raznih (iako glazbeno istih) sadržaja. Prema ranoromantičkoj izvodjačkoj praksi bilo je uobičajeno takve strofne popijevke pjevati s mnogo individualnog uživljavanja u sadržaj svake pojedine kitice. Citirajmo Goethea: „Bio je neumoran u studiranju najtočnijeg izražaja, koji se sastoji u tome da pjevač u okviru jedne melodije ističe najrazličitije značenje pojedinih strofa, znajući tako istovremeno ispuniti dužnost i liričara i epičara. Time prožet, rado bi dopuštao da ga molim, da i po nekoliko večernjih sati sve do duboko u noć ponavlja jednu te istu pjesmu sa svim njezinim nijansama na najtočniji način." ${ }^{\prime 16}$

13 Heinrich Christoph Koch, članak „Romanze”, Musikalisches Lexikon (...), Johann André, Offenbach 1802, šp. 1271.

14 Za vrijeme boravka u Grazu nastale su Livadićeve popijevke Alpenlied, Air du pauvre berger, op. 2 lautografna naslovna stranica nosi posvetu pjevačici Marie Michelberger i ističe Livadićevo članstvo u Musikvereinu u Grazu), i - vjerojatno - Nähe des Geliebten na riječi Johanna Wolfanga von Goethea, objavljena u zbirci Musikalische Blumenlese (Johann Lorenz Greiner, Graz 1824, sv. 2, br. 4). Isti je tekst uglazbio i Franz Schubert (D 162, op. 5, br. 2, 27. II 1815). Vjerojatno su u Grazu ili u godinama neposredno nakon boravka u tom gradu nastale i popijevke: O weine nicht!, Die Nonne, Vorüber, Vergessen i Das Traumbild, a i većina ostalih pjesama na njemačke tekstove koje Kuhač registrira u svom popisu, ali su danas izgubljene. Da je Livadić i nakon odlaska iz Graza podržavao kontakte s gradom svojih studija svjedoči činjenica, da su mu povremeno u Grazu objavljivane kraće kompozicije; od solo pjesama to su Wiegenlied i Entsagen, tiskane kao prilog u časopisu Iris 1857.

15 Zanimljivo je uočiti isti izražajni model u spomenutoj mladenačkoj Schubertovoj popijevci Nähe des Geliebten na tekst koji je uglazbio i Livadić (v. bilj. 14).

16 Tag- und Jahreshefte, Februar 1801. Radi se o Goetheovu opisu načina kojim je glumac $i$ pjevač Ehler vješto interpretirao strofne popijevke. Usp. i bilj. 5. 

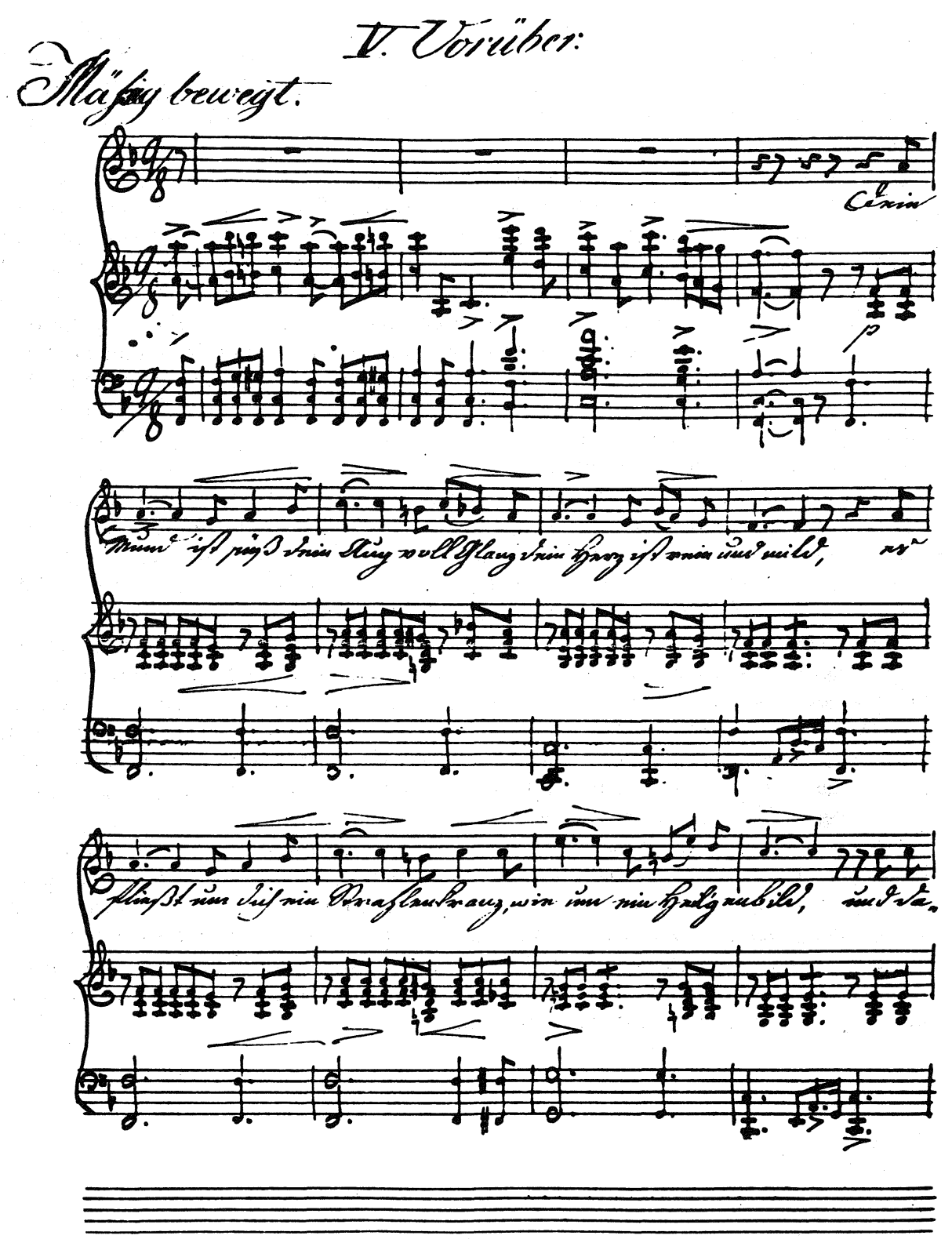

2 Ferdo Wiesner-Livadić, početak solo pjesme Vorüber u prijepisu F.Ks. Kuhača (NSB Zagreb) 
Navedenim značajkama svoje vokalne lirike Livadić se uklapa u krug takozvanih malih majstora prije i oko Schuberta, kao što su Anselm Hüttenbrenner (1794-1868), Jan Václav Tomášek (1774-1850), Conradin Kreutzer (1780-1849), Nikolaus Freiherr von Krufft (1779-1818), Anton Teyber (1754-1822) i Friedrich August Kanne (1778-1833).

Izbor pjesničkih tekstova ne sadrži samo biografske konotacije, nego pokazuje i stav skladatelja prema odredjenoj književnoj situaciji. Bilo bi zanimljivo jednom s tog aspekta analizirati tekstove koje su uglazbili naši skladatelji. Posebnost situacije u kojoj se oni nalaze u Hrvatskoj u preporodno doba očita je: jer kajkavska književna tradicija bila je nakon 1835. potisnuta, a suvremeno književno stvaralaštvo na štokavskom narječju nije još bilo dovoljno diferencirano u izrazu, pa se skladatelji često odlučuju za uglazbljivanje njemačkih tekstova. $O$ tome svjedoči i citat iz Livadićeva pisma Petru Preradoviću (19. XI 1868): „Vezdašne meni poznate pesme nisu dosta liričke i dramatičke, da bi mene uzhititi mogle, onako suhoparno glase, kakav je i tužni položaj naše domovine, $k$ tomu niti jednoga poznatoga veštoga pjevača, dakle mora se sve boljoj budućnosti ostaviti." Aludirajući potom na težinu političkih prilika Livadić zaključuje: „(...) gdo u takvih okolnostih more od serdca pievati? van: Miserere nobis!"17

Obrazlažući zašto više ne sklada, Livadić dakle ističe, da hrvatski tekstovi ne sadrže dovoljno lirizma, a niti dramatike da bi ga mogli oduševiti, odajući tako stav romantičara koji traži tekstove snažnog emotivnog naboja i izrazitih suprotnosti, ili profinjenog lirizma, a za dovršenu skladbu priželjkuje i odgovarajuće tumačenje.

Dva naizgled bliska strofna modela - romanca Livadića i strofna pjesma Lisinskoga - u suštini pripadaju raznim usmjerenjima evropskog Lieda prve polovine 19 . stoljeća. Dok se Livadićeva popijevka kreće u pijevnim i pregledno oblikovanim periodičnim strukturama $i$ jednakomjernim, sinhronim ravnima vokalnog i klavirskog glazbenog toka, odaje solo pjesma Lisinskoga diferencirane odnose vokalnosti i klavirskog parta s naznakama samostalne motivike i elementima deklamacije koja povremeno smisleno prekida pijevnu vokalnu liniju.

Ako je dakle i moguće prepoznati zajednički ranoromantički stilski nazivnik u vokalnoj lirici Lisinskoga i Livadića, očituje njihova solo pjesma više razlika nego sličnosti. Pri pažljivijoj analizi javlja se očita razlika u slogu i načinu upotrebe izražajnih sredstava, a te značajke vežu ovu dvojicu skladatelja uz dvije razne struje evropskog ranoromantičkog Lieda. Onoj Schubertovoj bliži je Lisinski, dok je Livadićeva vokalna lirika srodna onoj niza manjih majstora koji su djelovali koncem 18. i početkom 19. stoljeća i popijevci romantičkog klasicista Mendelssohna. 


\section{DER ZUFLUCHTSORT}

\section{Tekst}

Strofa Incipit teksta

1. „Ein armer Mann ohn Dach und Brod"

2. "Von Thür zur Thür lenkt er den Gang"

3. Ereilet hat die finstre Nacht

Stringendo, 6/8

$\mathrm{G}$ dur, c mol

modulacija u Es dur

Adagio lugubre, 6/8

Es

Es dur, zatim modulacija

u g mol; završetak na

dominanti g mola

Glazba

Formalno-izražajne

Elementi značajke
Prva i druga strofa obuhvaćene klavirski su velikim periodom pijevne uvod ( $2 \mathrm{t}$.) mel. linije

vokalna "tema" A

pred kraj 2. rečenice razbija se stroga simetrija periode;

dramatska poanta ostvarena ponavljanjem završnog dijela teksta

klavirski uvod (1 t.)

dramatska deklamacija

klavirski interludij

motiv uvo-

da + elem.

vok. teme

A $\left(\begin{array}{ll}4 & t .)\end{array}\right.$

4. „Dem Sinken nah"

A piacere,

Ces dur, modulacija

$\mathrm{u}$ es mol

dramatska deklamacija

(tremolo u klav. partu)

klavirska medjuigra (2 t.)

pijevna mala perioda

s dramatskom poantom

i modulativnim obratom

es mo

okret prema $7 / 5$

as-c-es-ges (dom. Des dura)

6. "Da öffnet sich

Grave, 4/4

mit dumpfen Klang"

Des dur

modulacija u $f$ mol

modulacija u F dur

7. "Willkommen, Armer, isti tempo, 4/4 labe dich"

$\mathrm{F}$ dur

8. "Weil fruchtlos du in aller Welt"

modulacija u Des dur

9. "Und plötzlich rieselts durch die Seel"

Poco mosso, 6/8

Des dur

es mol, Es dur

$10 . \quad$ So schlummert er

Tempo primo. Adagio und braucht kein Brod"

u drugom dijelu

klavirska medjuigra (3 t.)

dramatska deklamacija

elementi tonskog slikanja

zaostaja-

klavirskom partu (glissando) motiv

klavirska medjuigra (4 t.)

Sedma i osma strofa zasnova-

ne su kao velika perioda, čiji

drugi dio neočekivano modulira motiv

uz obrat pijevno-lirskog . uvoda

karaktera u dramatski (1 t.)

klavirski uvod (2 t.)

pijevna perioda proširena

ponavljanjem zadnjega stiha

klavirska medjuigra (2 t.)

zaostaja-

pijevna perioda

lični motiv

"tema" A

recitativ

uvoda 
The present study first draws parallels between the comprehensive ballads of Vatroslav Lisinski (1819-1854) and those of Johann Rudolf Zumsteeg (1760-1802). Proceeding from the tradition of the Zumsteeg ballad (which served as learning material to young Schubert as well), the ballads by Lisinski transcend the additive conception of Zumsteeg's pieces. The compositional techniques by means of which Lisinski aimed at uniting the disparate segments of the rather large lyrico-dramatic work are fairly diverse, displaying, however, characteristic "leitmotives" as a constant in the piano part. In his mature age as a composer, Lisinski cultivated the transstanzaic Lied consisting of the differentiated correlations of the vocal and piano parts.

Ferdo Livadic (Wiesner) (1799-1879) tried to create a mere lyrical atmosphere through which the lines of poetry would flow, which puts him in a position close to the aesthetic ideals set by Johann Wolfgang von Goethe. Livadic cultivated simple, mostly stanzaic, romance of a continuing and synchronized flow of the vocal part and the piano accompaniment. A set of songs written by Livadic to some German texts, probably during his student years at Graz (1816-1822), testifies to his affinity for the three-beat rhythm and the bel canto singability of the vocal part. Livadic employed this model in his piano Notturno (1822) most successfully.

The conclusion drawn is that the common early-Romantic stylistic denominator of the vocal lyricism of Lisinski and Livadic can never conceal their different conceptions of musical style and the use of the means of expression, which links the two composers to two different currents of European early-Romantic Lied: while Livadic followed the tradition of the pre-Schubertian, proto-Romantic solo-song to join the circle of the "little masters" active in the late 18th and early 19th century, Lisinski held a position closer to that of the classic author of Romanticism, Schubert. 